\title{
IDENTIFICATION OF TRYPANOSOMES IN WILD ANIMALS FROM SOUTHERN CAMEROON USING THE POLYMERASE CHAIN REACTION (PCR)
}

\author{
HERDER S.*, SIMO G.**, NKININ S.** \& NJIOKOU F.**,***
}

\section{Summary :}

One possible explanation of the maintenance of many historical foci of sleeping sickness in Central Africa could be the existence of a wild animal reservoir. In this study, PCR was used to detect the different trypanosome species present in wild animal captured by hunters in the southern forest belt of Cameroon (Bipindi). Trypanosomes were also detected by a parasitological method (Quantitative buffy coat: QBC). Parasite could not be isolated in culture medium (Kit for in vitro isolation: KIVI). Specific primers of $T$. brucei s.I., T. congolense forest type, T. congolense savannah type, T. vivax, T. simiae and T. b. gambiense group 1 were used to identify parasites in the blood of 164 animals belonging to 24 different species including ungulates, rodents, pangolins, carnivores, reptiles and primates. Of the 24 studied species, eight were carrying $T$. b. gambiense group 1 . Those parasites pathogenic to man were found in monkeys/Cercocebus torquatus and Cercopithecus nictitans), in ungulates (Cephalophus dorsalis and C. monticola), in carnivores (Nandinia binotata and Genetta servalina) and in rodents (Cricetomys gambianus and Atherurus africanus). 13 species (54\%) were carrying T. brucei s.l. identified as non-gambiense group 1

KEY WORDS : sleeping sickness, wild animal, reservoir, PCR, T. b. gambiense, forest belt, Cameroon.
Résumé : IDENTIFICATION PAR PCR DES TRYPANOSOMES CHEZ LES animauX SAuvages du SUd-Cameroun

Une explication possible du maintien de nombreux foyers historiques de la maladie du sommeil en Afrique centrale pourrait être l'existence d'un réservoir animal sauvage. Dans cette étude, la PCR a été utilisée pour identifier les différentes espèces de trypanosomes hébergées par des animaux sauvages capturés par des chasseurs dans la forêt du Sud-Cameroun (Bipindi). Les trypanosomes ont également été détectés par une technique parasitologique (QBC: Quantitative buffy coat). Les parasites n'ont pas pu être isolés sur milieu de culture (KIVI : Kit for in vitro isolation). Des amorces spécifiques de T. brucei s.l.

T. congolense type forêt, T. congolense type savane, T. vivax, T. simiae et T. b. gambiense groupe 1 ont été utilisées pour identifier les trypanosomes dans le sang de 164 animaux sauvages appartenants à 24 espèces différentes et comprenant des ongulés, des rongeurs, des pangolins, des petits carnivores, des reptiles et des primates. Sur les 24 espèces étudiées, huit étaient porteuses de T. b. gambiense groupe 1. Ces parasites potentiellement pathogènes pour l'homme ont été trouvés chez des singes (Cercocebus torquatus et Cercopithecus nictitans), chez des ongulés (Cephalophus dorsalis et C. monticola), chez des petits carnivores (Nandinia binotata et Genetta servalina) et chez des rongeurs (Cricetomys gambianus et Atherurus africanus). 13 espèces (54\%) étaient porteuses de T. brucei s.l. identifié comme non-gambiense groupe 1

MOTS CLÉS : maladie du sommeil, animaux sauvages, réservoir, PCR, T. b. gambiense, forêt, Cameroun.

animal reservoir for $T$. brucei rhodesiense has been demonstrated by inoculating a volunteer with trypanosomes isolated from a bushbuck (Tragelaphus scriptus) (Heisch et al., 1958). Similarly, the possible existence of an animal reservoir for gambian sleeping sickness has also been investigated in West Africa. However, the isolation of $T . b$. gambiense-like trypanosomes have largely been ignored because of the avirulence of these organism both in man and in domestic or wild animals (Molyneux, 1973). Several workers have shown that domestic animals are capable of acting as suitable reservoir hosts (Van Hoof, 1947; Gibson et al., 1978; Mehlitz et al., 1982). Previous studies carried out in West and Central Africa have shown that wild mammals can harbour trypanosomes including T. brucei s.l. (Burridge et al., 1966; Allsopp, 1972; Mehlitz, 1982; Komoin-Oka et al., 1994; Truc et al., 1997a, 1997b). Besides, T. b. gambiense is capable of 
infecting a wide range of wild animals under experimental conditions (Frézil \& Carnevale, 1976).

In the past, the major difficulty in demonstrating that T. b. gambiense also infects mammals other than man was the lack of techniques capable to differentiate trypanosomes in naturally infected hosts (Molyneux, 1973). The development of new molecular markers has enable the detection of $T$. brucei s.l. subspecies in naturally infected hosts and vectors (Herder et al., 1997; MacLeod et al., 1999; Biteau et al., 2000).

In this study, PCR (Polymerase chain reaction) was used to identify trypanosome species harboured by wild animals from the south cameroonian region. Trypanosomes were also detected by QBC (Quantitative buffy coat; Bailey \& Smith, 1992), a parasitological technique which does not allow the distinction between the different subspecies. Parasites were also isolated on KIVI (Kit for in vitro isolation; Aerts et al., 1992) culture medium.

\section{MATERIALS AND METHODS}

\section{STUDY AREA}

T The sleeping sickness focus of Bipindi $\left(3^{\circ} 06^{\prime} \mathrm{N}\right.$, $10^{\circ} 30^{\prime} \mathrm{E}$ ) is situated in south province of Cameroon, approximately $75 \mathrm{~km}$ off the coast. It is a rainforest area characterized by a typical equatorial climate with four seasons. The main activity is extensive peasant agriculture characterized by burned ground farming with numerous encampments. Hunting is also an important resource for self consumption and for sale.

\section{COLLECTION OF SAMPLES}

Sampling of blood from wild animals was done in the villages of Lambi and Bidjouka (Bipindi) during the rainy season in July and in October 1999. The animals caught by trapping or firearm were brought back to the village. We did not have any incentive action on the hunters since only the animals already killed and intended for sale were sampled. Moreover, the hunters were not informed of our coming since we had met them on the markets (meat points of sale). When it was possible, an aseptic sample of blood was then taken to inoculate KIVI medium. A second sample was taken on EDTA tube for QBC and PCR tests. The QBC analyses were carried out within two hours after sampling; thin blood smears were then visualised on samples positive by QBC.

\section{DNA ISOLATION}

Samples were treated with Ready AMP ${ }^{\mathrm{TM}}$ genomic purification kit (Promega, Madison, WI, USA) as described by Penchenier et al. (1996). Supernatants contai- ning single stranded DNA were stored at $4^{\circ} \mathrm{C}$ or used directly as template for PCR amplification.

\section{PCR ANALYSIS}

Specific primers for T. brucei s.l. (TBR1 \& 2; Moser et al., 1989), T. congolense "forest type" (TCF1 \& 2; Masiga et al., 1992), T. congolense "savannah type"(TCS1 \& 2; Majiwa et al., 1994), T. vivax (TVW1 \& 2; Masiga et al., 1992), T. simiae (TSM1 \& 2, Masiga et al., 1992) and T. b. gambiense "group 1" (TRBPA1 \& 2; Herder et al., 1997) when positive with TBR1 and 2, were used to amplify DNA extracted from animal blood.

PCR reactions were performed in $25 \mu \mathrm{l}$ of $10 \mathrm{mM}$ Tris$\mathrm{HCl}(\mathrm{pH} 9.0), 50 \mathrm{mM} \mathrm{KCl}, 0.1 \%$ Triton X100, $1.5 \mathrm{mM}$ $\mathrm{MgCl}_{2}, 0.2 \mathrm{mM}$ of each dNTP, 20 picomoles of each primer, $5 \mu \mathrm{l}$ of template DNA and one unit of Taq DNA polymerase (Promega). Amplifications were carried out in a thermocycler (Techne Gene E) programmed for 40 cycles of 30 seconds at $92^{\circ} \mathrm{C}, 30$ seconds at $60^{\circ} \mathrm{C}$ and one minute at $72^{\circ} \mathrm{C}$ for TRBPA and with an annealing temperature of $55^{\circ} \mathrm{C}$ for $T$. brucei s.l. (TBR) and $60^{\circ} \mathrm{C}$ for the others (T. congolense forest and savannah type, T. simiae and T. vivax). Amplification products were resolved on $1.5 \%$ agarose gel, or on $4 \%$ agarose $/ 10 \%$ acrylamide gel for the procyclic acidic repetitive protein (PARP) gene (TRBPA: Fig. 1).

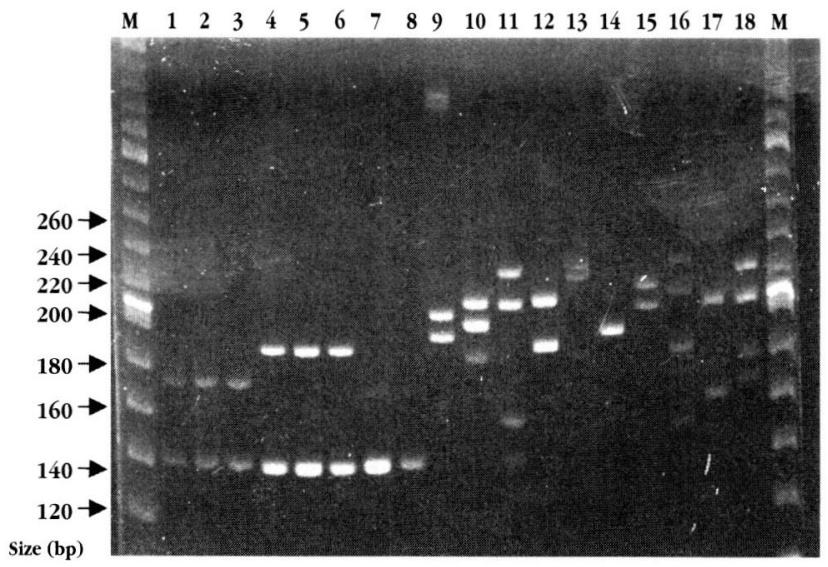

Fig. 1. - Results of the PCR amplification using TRBPA primers on different trypanosome isolates.

M: Molecular weight marker (MWM) 100/20 base pair (bp) ladder. Lane 1 to 8: T. $b$. gambiense group 1; lane 9 to 12: T. $b$. gambiense non group 1; lane 13: T. b. rhodesiense, lane 14 to 18: T. b. brucei.

\section{RESULTS}

64 animals belonging to 24 species were sampled: $54(33 \%)$ primates, $45(27.4 \%)$ ungulates, 39 $(23.8 \%)$ rodents, five $(3 \%)$ reptiles, $10(6.1 \%)$ pangolins and $11(6.7 \%)$ carnivores (Table I). Trypanosomes were observed in three out of $50 \mathrm{QBC}$ tests 


\begin{tabular}{|c|c|c|c|c|c|c|c|c|}
\hline \multirow[b]{2}{*}{ Common name } & \multirow[b]{2}{*}{ Species name } & \multirow{2}{*}{$\begin{array}{l}\text { Total } \\
\text { tested }\end{array}$} & \multicolumn{6}{|c|}{ Species of trypanosome } \\
\hline & & & $\mathrm{TB}$ & TBG1 & TCRF & TCS & TV & TSM \\
\hline Brush-tailed porcupine & Atherurus africamus & 20 & 5 & 2 & - & 2 & 2 & 2 \\
\hline Giant rat & Cricetomys gambianus & 17 & 2 & 3 & - & 1 & 1 & - \\
\hline \multirow[t]{2}{*}{ Sun squirrel (red-legged) } & Heliosciurus rufobrachium & 2 & 1 & - & - & - & - & - \\
\hline & Rodents Sub-Total & 39 & 8 & 5 & - & 3 & 3 & 2 \\
\hline Duiker (blackstiped) & Cephalophus dorsalis & 7 & 2 & 1 & - & - & 1 & - \\
\hline Blue Duiker & Cephalophus monticola & 30 & 3 & 1 & - & 1 & 2 & - \\
\hline Duiker (ogilby's) & Cephalophus ogilbyi & 1 & - & - & - & - & - & - \\
\hline Duiker (yellow-backed) & Cephalophus sylvicultor & 2 & - & - & - & 1 & - & - \\
\hline Duiker (peter's) & Cephalophus callipygus & 1 & - & - & - & - & - & - \\
\hline Sitatunga & Tragelaphus spekei & 3 & - & - & - & - & - & - \\
\hline \multirow[t]{2}{*}{ Royal antelope } & Neotragus pygmaeus & 1 & - & - & - & - & - & - \\
\hline & Ungulates Sub-Total & 45 & 5 & 2 & - & 2 & 3 & - \\
\hline Mangabey (white-eyelid) & Cercocebus torquatus & 1 & - & 1 & - & - & - & - \\
\hline Moustached monkey & Cercopithecus cepbus & 13 & 1 & - & - & 1 & 1 & - \\
\hline Mona monkey & Cercopithecus mona & 3 & - & - & - & - & 1 & - \\
\hline Greater white-nosed monkey & Cercopithecus nictitans & 16 & 2 & 2 & - & - & 2 & - \\
\hline Mandrill & Mandrillus sphinx & 4 & - & - & - & - & - & - \\
\hline Dwarf guenon & Miopithecus talapoin & 12 & 2 & - & - & - & 3 & - \\
\hline Galago & Perodicticus potto & 2 & 1 & - & - & - & 1 & - \\
\hline \multirow[t]{2}{*}{ Golden Potto } & Arctocebus calabarensis & 3 & 1 & - & 1 & - & - & - \\
\hline & Primates Sub-Total & 54 & 7 & 3 & 1 & 1 & 8 & - \\
\hline Long-tailed pangolin & Manis tetradactyla & 5 & 1 & - & - & - & - & - \\
\hline \multirow[t]{2}{*}{ Tree pangolin } & Manis tricuspis & 5 & 1 & - & - & - & 1 & - \\
\hline & Pangolins Sub-Total & 10 & 2 & - & - & - & 1 & - \\
\hline Palm civet (two spotted) & Nandinia binotata & 8 & 1 & 2 & - & - & 1 & - \\
\hline Small-spotted genet & Genetta servalina & 2 & - & 1 & - & 1 & 1 & - \\
\hline \multirow[t]{2}{*}{ African civet } & Viverra civetta & 1 & - & - & - & - & - & - \\
\hline & Carnivores Sub-Total & 11 & $\mathbf{1}$ & 3 & - & 1 & 2 & - \\
\hline \multirow[t]{4}{*}{ Monitor lizard } & Varanus niloticus & 5 & - & - & - & - & 1 & - \\
\hline & Reptiles Sub-Total & 5 & - & - & - & - & 1 & - \\
\hline & Total & 164 & 23 & 13 & 1 & 7 & 18 & 2 \\
\hline & & & $14 \%$ & $8 \%$ & $0.6 \%$ & $4.3 \%$ & $11 \%$ & $12 \%$ \\
\hline
\end{tabular}

Table 1. - PCR results on animal blood using different specific primers. TB: T. brucei non gambiense group 1; TBG1: T. b. gambiense group 1; TCRF: T. congolense "forest type"; TCS: T. congolense "savannah type"; TV: T. vivax, TSM: T. simiae.

but only one was confirmed positive by PCR and identified as T. vivax.

Seven of the 35 KIVI were positive, but the parasites did not grow when transfered into Cunnigham culture medium. For these seven positive samples, three were confirmed by PCR: one $T$. brucei s.l./T. vivax mixed infection and two T. vivax single infections.

The PCR results obtained with $T$. brucei s.l. (TB), T. $b$. gambiense group 1 (TBG1), T. congolense "forest" (TCF), T. congolense "savannah" (TCS), T. vivax (TV) and T. simiae (TSM) specific primers are given in Table I. The prevalences observed were as follows:

- $22 \%$ for T. brucei s.l. of which $8 \%$ were T. b. gambiense group 1 ,

- $11 \%$ for T. vivax,

- $4.3 \%$ for "savannah type" T. congolense,

- $1.2 \%$ for T. simiae,

- $0.6 \%$ for "forest type" T. congolense.

T. brucei s.l. (non-gambiense group 1) and T. b. gambiense group 1 DNA were respectivelly detected in 13 (54\%) and eight (33.3\%) of the 24 animal species studied. Trypanosomes pathogenic to Man (TBG1) were found in two species of rodents (Atherurus africanus and Cricetomys gambianus), in two species of ungulates (Cephalophus dorsalis and C. monticola), in two species of carnivores (Nandinia binotata and Genetta servalina) and in two species of monkeys (Cercocebus torquatus and Cercopithecus nictitans). T. vivax is fairly represented as $11 \%$ of the animals were found positive: it was present in all groups of animals examined. 12 mixed infections were identified:

- four with T. brucei non-gambiense group 1 and TV (one $M$. talapoin, one A. africanus, one $N$. binotata and one P. potto),

- three with TBG1 and TV (one C. gambianus, one C. nictitans and one C. dorsalis),

- one with T. brucei non-gambiense group 1 and TCF (A. calabarensis),

- one with T. brucei non-gambiense group 1 and TCS (A. africanus),

- one with TBG1 and TCS (C. gambianus),

- one with TV and TSM (A. africanus),

- and one with TBG1, TCS and TV (G. servalina). 


\section{DISCUSSION}

T The detection of trypanosomes in the blood is often made difficult because of the relatively poor sensitivity of the parasitological techniques and parasitaemia that is often low and fluctuating. These was also the case in this study where the QBC method detected trypanosomes in only $6 \%$ of our samples ( $24.5 \%$ by PCR). Only three out of seven positive KIVI were confirmed by PCR suggesting that trypanosome species other than those detected by the specific primers used in this study could be present in our samples.

Because of its high sensitivity and specificity, PCR allows detection and identification of trypanosome species within naturally infected hosts thus avoiding selection bias introduced when parasites are grown in culture for example. This technique shows the important number of trypanosome species harboured by wild animals in the forest belt of southern Cameroon. Nevertheless, a PCR positive result indicates the presence of the corresponding parasite DNA and not necessarily an active infection.

The fact that $8 \%$ of the animals examined were positive for $T$. b. gambiense group 1, the parasite responsible in $80 \%$ of the cases for the chronic form of the disease in West and Central Africa (Gibson, 1986), is surprising as previous authors rarely reported the presence of this parasite in wild game (Truc et al., 1997a). Five of the 13 animals positive for TBG1 by PCR were rodents (Atherurus africanus and Cricetomys gambianus). This last rodent is an excellent laboratory host for T. b. gambiense and tse-tse flies feed avidly on this animal in experimental conditions (Larivière, 1957; Van den Berghes et al., 1963). It has been demonstrated for $C$. gambianus that tse-tse flies are able to penetrate an experimentally constructed burrow to feed on them (Molyneux, 1971). These flies are probably attracted by the more favorable humidity and temperature conditions in the burrow and possibly odours. Moreover, it is possible for C. gambianus to be bitten by G. palpalis and G. caliginea because they are found together in peridomestic habitats in Cameroon (Nash, 1970; Molyneux, 1973).

Three monkeys (Cercocebus torquatus and Cercopithecus nictitans) among 54 non-human primates tested were positive for TBG1 by PCR. Several experimental transmissions have been carried out on different species of monkeys (Cercopithecus, Cercocebus, Erythrocebus). Important transmission indices have been observed with the Mangabey (Cercocebus galeritus agilis) though infection under experimental conditions have been difficult (Van Hoof, 1947). However, blood meal analysis of tsetse flies show that very few of them were taken from primates other than man (Jordan et al., 1961).
Despite the low number of small carnivores, two Nandinia and one Genetta were found positive for $T$. $b$. gambiense group 1. As far as we know, it is the first time that $T$. $b$. gambiense group 1 was identified in such wild animals.

Several ungulates species (Kobus kob, Alcelaphus bubalus) were found positive for T. b. gambiense-like trypanosomes in West Africa (Mehlitz, 1986; Guedegbe et al., 1992; Truc et al., 1997a). Nevertheless, our study is the first report suggesting the presence of gambian trypanosomes in wild ungulates (duiker and blue duiker) in the central African forest belt.

Nevertheless, the presence of $T . b$. gambiense strains in a particular animal does not mean that such an animal is an important reservoir host.

There is an urgent need to confirm this presence of T. b. gambiense in wild animals by a large scale study of specimens sampled during various seasons of the year and a systematic use of KIVI in order to increase the chances of isolating parasite stocks for mass culture and isoenzyme characterization. Complementary studies remain necessary given the low number of specimens for some animal species included in our study. There is also need to study the trophic preferences of vectors and quantify the man/wild animal reservoir contacts within a given locality. These studies should enable a better comprenhension of epidemiology of sleeping sickness, on the phenomenon of cyclical resurgence, the maintenance and spread of the disease.

\section{ACKNOWLEDGEMENTS}

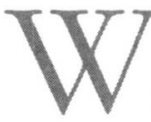
e thank Pr G. Duvallet and Dr C. Laveissière for critical reading of the manuscript, X. Pourrut, M. Mgbédié, E. Mooh and S. Bahebegue for excellent technical assistance.

\section{REFERENCES}

Aerts D., Truc P., Penchenier L., Claes Y. \& Le Ray D. A kit for in vitro isolation of trypanosomes in field: first trial with sleeping sickness patients in the Congo Republic. Transactions of the Royal Society of Tropical Medicine and Hygiene, 1992, 86, 394-395.

Allsopp R. The role of game animals in the maintenance of endemic and enzootic trypanosomiasis in the Lambwe Valley, South Nyanza District, Kenya. Bulletin of the World Health Organisation, 1972, 47, 735-746.

BAILEY J.W. \& SMITH D.H. The use of acridine orange QBC technique in the diagnosis of African trypanosomiasis. Transactions of the Royal Society of Tropical Medicine and Hygiene, 1992, 86, 630.

Biteau N., Bringaud F., Gibson W., Truc P. \& Baltz T. Characterization of Trypanozoon isolates using a repeated 
coding sequence and microsatellite markers. Molecular and Biochemical Parasitology, 2000, 105 (2), 185-201.

Burridge M.J., Pullan N.B., Reid H.W., Sutherst R.W. \& Wain E.B. Survey of trypanosomiasis in wild animals in south Busia, Uganda. I.S.C.T.R.C., 1966, OUA/STRC, $11^{\text {th }}$ meeting, Nairobi, 5 pages.

Frézil J.L. \& Carnevale P. Le problème du réservoir de virus et du maintien des foyers de trypanosomiase humaine en Afrique Centrale. Cahiers ORSTOM, série Entomologie médicale et Parasitologie, 1976, 4, 307-313.

Gibson W.C. Will the real Trypanosoma brucei gambiense please stand up. Parasitology Today, 1986, 2, 255-257.

Gibson W., Mehlitz D., Lanham S.M. \& Godfrey D.G. The identification of Trypanosoma brucei gambiense in Liberian pigs and dogs by isoenzymes and by resistance to human plasma. Tropenmedizin und Parasitologie, 1978, $29,335-345$

Guedegbe B., Verhulst A., Van Meirvenne N., Pandey V.S. \& Dоко A. Indications sérologiques de l'existence d'un réservoir sauvage de Trypanosoma brucei gambiense dans la réserve de biosphère de la Pendjari en République du Bénin. Annales de la Société Belge de Médecine Tropicale, 1992, 72 (2), 113-120.

Heisch R.B., McMahon J.P. \& Manson-Bahr P.E.C. The isolation of Trypanosoma rhodesiense from a bushbuck. British Medical Journal, 1958, 2, 1203-1204.

Herder S., Grébaut P., Eouzan J.P. \& Cuny G. De nouveaux marqueurs moléculaires pour l'étude de la variabilité génétique de Trypanosoma brucei s. 1. Statégies de lutte et de surveillance dans le paludisme et les trypanosomiases. Bulletin de liaison et de Documentation de l'OCEAC, 1997, 30, 81.

Jordan A.M., Lee-Jones F. \& Weitz B. The natural hosts of tsetse flies in the forest belt of Nigeria and the southern Cameroons. Annals of Tropical Medicine and Parasitology, 1961, 55, 167-179.

Komoin-Oka C., Truc P., Bengaly Z., Formenty P., Duvallet G., Lauginie F., RaAth J.P., N'Depo A.E.N. \& Leforban Y. Étude de la prévalence des infections à trypanosomes chez différentes espèces d'animaux sauvages du parc national de la Comoé en Côte d'Ivoire : résultats préliminaires sur la comparaison de trois méthodes de diagnostic. Revue Elevage et Médecine Vétérinaire des Pays Tropicaux, 1994, 47, 189-194.

LARRIVIÈre M. Réceptivité de Cricetomys gambianus (Rat de Gambie) au Trypanosoma gambiense. Comptes Rendus de la Société de Biologie, 1957, 151, 1349.

MacLeod A., Turner C.M.R. \& TAit A. A high level of mixed Trypanosoma brucei infections in tsetse flies detected by three hypervariable minisatellites. Molecular and Biochemical Parasitology, 1999, 102, 237-248.

Majiwa P.A.O., Thatthi R., Moloo S.K., Nyeko J.H.P., Otieno L.H. \& MaloO S. Detection of trypanosome infections in the saliva of tsetse flies and buffy-coat samples from antigenaemic but aparasitemic cattle. Parasitology, 1994, 108, 313-322.

Masiga D.K., Smyth A.J., Ayes P., Bromidge T.J. \& Gibson W.C. Sensitive detection of trypanosomes in tsetse flies by DNA amplification. International Journal for Parasitology, 1992, 22, 909-918.

Mehlitz D. Trypanosomes in African wild mammals. In: Baker (J.R.), Ed., Perspectives in Trypanosomiasis Research. Chichester, Research Studies Press, John Wiley \& Son, Ltd, 1982, 25-35.

Mehlitz D. Le réservoir animal de la maladie du sommeil à Trypanosoma brucei gambiense. Études et Synthèses de l'IEMVT, 1986, 18, 156 pp.

Mehlitz D., Zillmann U., ScotT C.M. \& Godfrey D.G. Epidemiological studies on the animal reservoir of gambiense sleeping sickness. III. Characterization of Trypanozoon stocks by isoenzymes and sensitivity to human serum. Tropenmedizin und Parasitologie, 1982, 33, 113-118.

Molyneux D.H. Observations of naturally occuring mammals as reservoir hosts of Trypanosoma brucei gambiense. International Scientific Committee for Trypanosomiasis Research, 13th Meeting Lagos. Commission for Technical Cooperation in Africa South of the Sahara, 1971, 81-84.

Molyneux D.H. Animal reservoir and gambian trypanosomiasis. Annales de la Société Belge de Médecine Tropicale, 1973, 53, 605-618.

Molyneux D.H. Animal reservoirs and residual foci of Trypanosoma brucei gambiense sleeping sickness in West Africa. Insect Science Application, 1980, 1, 59-63.

Moser D.R., Cook G.A., Ochs D.E., Bailey C.P., McKane M.R. \& DONELSON J.E. Detection of Trypanosoma congolense and Trypanosoma brucei subspecies by DNA amplification using the polymerase chain reaction. Parasitology, 1989, 99, 57-66

NaSH T.A.M. The ecology of West African riverine species of tsetse in relation to man-fly contact. In: The African Trypanosomiases; H.W. Mulligan. Allen \& Unwin: London. 1970, 602-613.

Penchenier L., Dumas V., Grébaut P., Reifenberg J.M. \& Cuny G. Improvement of blood and fly gut processing for PCR diagnosis of trypanosomosis. Parasite, 1996, 4, 387-389.

Truc P., Formenty P., Diallo P.B., Komoin-OKa C. \& LaugiNIE F. Confirmation of two distinct classes of zymodemes infecting man and wild animals in Côte d'Ivoire: suspected differences in pathogenicity. Annals of Tropical Medicine and Parasitology, 1997a, 91, 951-956.

Truc P., Formenty P., Duvalet G., Komoin-OKa C., Diallo P.B. \& LAUGINIE F. Identification of trypanosomes isolated by KIVI from wild mammals in Côte d'Ivoire: diagnostic, taxonomic and epidemiological considerations. Acta Tropica, 1997b, 67, 187-196.

Van den Berghe L., Chardome M. \& Peel E. Démonstration par transmission cyclique du rôle possible de quatre petits mammifères africains comme réservoirs de trypanosomoses du groupe brucei. Annales de la Société Belge de Médecine Tropicale, 1963, 43, 157-162.

VAN Hoof L.M.J. Observations on trypanosomiasis in the Belgian Congo. Transactions of the Royal Society of Tropical Medicine and Hygiene, 1947, 40, 728-761.

Reçu le 10 avril 2002 Accepté le 25 septembre 2002 